\title{
Play in Teaching Taiwanese Romanization Spelling-A Case of Two Grade 5 Classes From Two Schools
}

\author{
Yu Shu-Fan, Chen Feng-Ru \\ National Hsinchu University of Education, Hsinchu City, Taiwan
}

\begin{abstract}
The purpose of this study is to explore the real condition and effects of play teaching on Taiwanese Romanization for Grade 5 students in Ba Dou Area in Keelung, and to investigate the difficulties in the process and solving methods. Play is a motivational tool to encourage and stimulate learning and attention. Based on a case of study, the subjects were a total of 53 students in grade 5 from two different schools, taught by a researcher. Throughout 13 weeks research, the data was collected and analyzed by means of classroom observation, interviewing the students, or reflective journal, surveys of opinions from students and Taiwanese teachers and document analysis based on SPSS. Play in Teaching Taiwanese Romanization Spelling experimental group of consonants, vowels, tones, spelling and overall performance scores were significantly higher than the control group students $F(1,50)=4.46$, and 4.95, And 5.86, and 84.77, and $21.85(p<0.05)$. Research findings are summarized as follows: (1) By incorporating play into Taiwanese Romanization Spelling, the researcher found the interaction between the teacher and students, the students' reaction on Taiwanese Romanization Spelling learning, and the performance to be highly different to normal Taiwanese class; (2) Having play in teaching Taiwanese Romanization Spelling has five significant advantages, both in teaching and learning aspects: a. Promoting the students' participation in learning Taiwanese Romanization Spelling; b. Increasing interaction between the teacher and students; c. Changing the attitudes in learning and using Taiwanese Romanization Spelling; d. Improving social ability by having play with classmates; and e. Examining learning impacts, and achieving the objective of repeated practice; (3) The researcher encountered and finally solved some difficulties in Taiwanese Romanization Spelling, and many differences between the students from dissimilar classes. Based on the results as above, the suggestions for Taiwanese Romanization Scheme and further study were proposed. Taiwanese is a brand new subject, this research provides mother tongue teachers a new method in teaching to solve the problems they have met and also it is the first research on the purpose to help children learn Taiwanese Romanization Spelling happily and effectively.
\end{abstract}

Keywords: Taiwanese Romanization Scheme, action research, play and game

\section{Introduction}

Language is part of culture and cultureis delivered by language. Without written language, all culture withers like a fading plant which will be faded soon. Cai Pei Huo proposed using Romanization Spelling in Taiwanese so that Taiwanese could expand farther and farther (Xu, 2002, p. 3). Taiwanese is sound writing or

Yu Shu-Fan, Institute of Taiwan Languages and Language Teaching, National Hsinchu University of Education.

Chen Feng-Ru, Associate Professor, Institute of Taiwan Languages and Language Teaching, National Hsinchu University of Education. 
alphabet writing language, yet most of the people in Taiwan neglect it (Lin, 2005).

Mother tongue has become formal subject in all of the elementary schoolsin Taiwan since 2001, then Taiwanese Romanization Spelling started to be used and taught in 2006. More than a decade of Mother tongue teaching, we have surveyed in order to understand the learning problems they have faced and how they interact with and use it. Most of the students don't seem to enjoy Taiwanese Romanization Spelling and some of them even dislike it, and therefore we tried to attract motivate them by using different teaching methods. The ability of Taiwanese Romanization Spelling will help them speak, read and write which are the foundations to expand Taiwaneseand we must take care to preserve our national heritage. The purpose of this research is that we sought to use play and games in Taiwanese Romanization Spelling teaching and analysed the data to find out if it was useful and effective to improve the interesting in learning Taiwanese Romanization Spelling.

\section{Limitation of the Research}

There is once in a week curriculum which is only forty minutes in the whole class, indeed it is not enough to be familiar with Taiwanese learning for the students. Most of the students speak Taiwanese with family members or classmates but that is for oral speaking not including Taiwanese Romanization Spelling system. It seems that most of the students are not familier with it and even some of them have changed different Mother Tongue $^{1}$ every semester. In this research, there are two groups of grade five students from two elementary schools. Both of the experimental group and control group were taught by the same teacher at the same semester on different week day.

\section{Purpose of This Research}

The policy of Mother Tongue Education in Taiwan has been proceeding more than a decade in the elementary schools in Taiwan. The purpose of this research tried to detect the effect about learning attitude, problems in Taiwanese Romanization Spelling. To discover the interest in learning Taiwanese Romanization Spelling system of grade five students by using play and to compare and analyse it between the experimental group and control group. We also wanted to solve insufficient teaching time ${ }^{2}$, the skill of using Taiwanese Romanization Spelling system andmotitvation. We like to support another method to Mother Tongue teachers in teaching Taiwanese. Two sets of research findings provide an empirical background for this research. The first set of findings refers to the impact of the coherence of a text on comprehension and the second considers the benefits of active processing for learning.

\section{Participants}

53 particpants are grade five students in the experimental group and control group, living in Ba Dou area in Keelung, they were taught by the researcher during 13 weeks. Experimental group has 23 students but one of them is a girl who has learning disability, and the control group has 30 students. The researchers has no right to

\footnotetext{
${ }^{1}$ There are more than 14 Mother Tongues in Taiwan, and the students have the right to change their Mother Tongue at the beginning of the semester. The spelling systems of all are different and this causes the students much trouble in learning. I would like to thank my professor Dr. Li Chin An and my friend, Valerie Leigh McDermott, who help and encourage me finish my research.

${ }^{2}$ Both of these elementary school they have language classes as follow: Grade 1 to Grade 2 has five periods of mandarin, Grade 3 to 4 has six periods of mandarin which contains one period of reading comprehension and Grade 5 to Grade 6 has the same as Grade 3 to 4. We start teaching English in Grade 3, and the students are taught two periods once a week. On the other hand, we start teaching Taiwanese in Grade 1 but the students are taught one period once a week. Comparing the language subjects in Taiwan, Taiwanese faces the limitation of time which is hard to teach listening, speaking, reading, and writing of Taiwanese well in 40 minutes.
} 
choose students in this research because of the students were placed in random access. This research was observed by the class' preceptors during the 13 weeks.

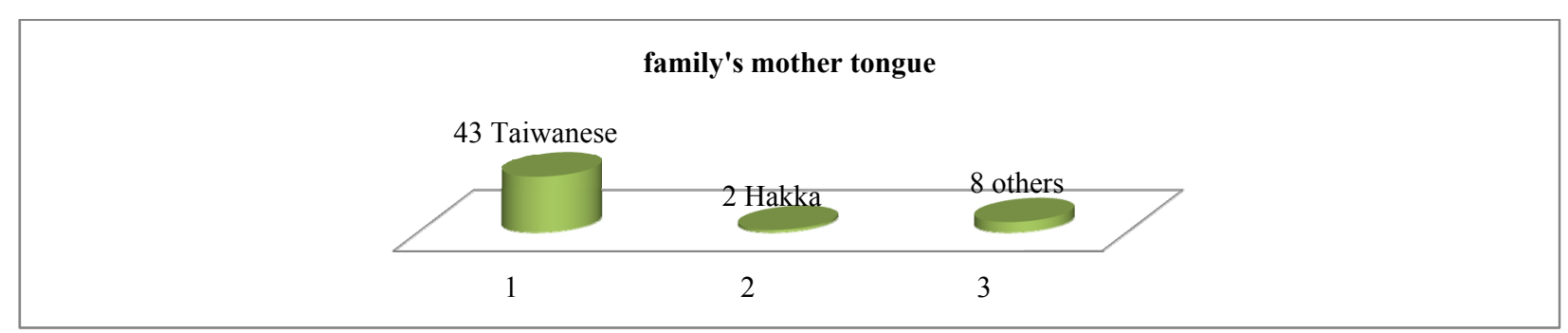

Figure 1. Background of mother tongue.

Most of the students' mother tongue is Taiwanese but two of them are Hakka and the rest of the eight students have another mother tongue ${ }^{3}$. Therefore, 10 of the students' family don't speak Taiwanese at home and this language background that means the students don't have enough opportunity to hear or speak Taiwanese at home.

\section{Procedure}

Before the research began, all of the participants took the survey and pretests, and they also took the survey and posttests after teaching. During the 13 weeks, the researcher interviewed and counseled with the participants after each class which provided the researcher more information in order to adjust the games and curriculums in the following weeks teaching.

\section{What Is Play?}

Play always happens in our daily lives, yet people don't focus on it. Some people think that play is part of our own amusement and it helps us to release the stress from the real society (Zhong, 2003). But why play? Learning is difficult to the young kids, thereforeplayisan import role to the young kids. Play helps the young kids and teachers to dare with new knowledge. To participate in play, the young kids need to pay more attention in class which is the motitation to the kids. John Adair described that the words motive or motivation, however, suggest that something within you is at work, impelling or driving you forwards. And it may be a need, desire or emotion, but it leads you to and and to act in a certain way. A motive, then, is an inner need or desire which is conscious, semi-conscious or perhaps unconscious operates on your will and leads to action of one kind or another (Adair, 1996). Of course you may have motives that do not issue in any action. Play is the motivation to the young kids to learn new knowledge incidentally. Play is not only play which plays an import role. Some provide more practicing than the other, but some are not. Therefore, we said that is the quality of game (Andrew, 1984, p. 2). Stipek refers to that motivation is relevant to learning because learning is an active process requiring conscious and deliberate activity. Even the most able students will not learn if they do not pay attention and exert some effort. If students are to benefit maximally from the educational curriculum, educators must provide a learning context that motivates students to engage in learning activities. Johnan Huizinga ${ }^{4}$ provides play another definitation which is explained in the sight of physiology (Zhong, 2003). Play has the

\footnotetext{
3 The government of Taiwan had identified 16 kinds of mother tongues in Taiwan. http://www.apc.gov.tw/portal/docList.html?CID=6726E5B80C8822F9

${ }^{4}$ Johan Huizinga (Dutch: [ jo : fan fœyzı yra : ]; (December 7, 1872-February 1, 1945), was a Dutch historian and one of the founders of modern cultural history. Retrieved from https://en.wikipedia.org/wiki/Johan_Huizinga
} 
necessary or usful function of science point which is accepted by people. Play continues to be taken seriously in the academic community, as evidenced by the scope of play scyolarship across the human life span (Holzman, 2009; Hughes, 2010; Kuschner, 2009; Smith, 2010; Wood, 2013), across different contexts. Play and playfulness are considered to be lifelong activities: Far from tailing off towards the end of childhood, play continues to develop in complexity and challenge to human being (Broadhead, 2004, pp. 53-55; Wood, 2013, pp. 6-10). Most of the researchers are still hard to set up the definitation of it because it indicates the potential variation and complexities of play as a social and cultural practice. Play activities involve a wide range of behaviours, actions and interactions, which may have multiple meanings for the player. Play can be regarded as deeply serious and purposeful, or trivial and purposeless. Therefore, we may conclude that play is motivation, creativity, and learning.

\section{Game Is Play, Play Is Game}

What exactly is play? Is it as same as a game? In the early stages, there's no agreement between the definition of play and game. Chen (2000) concluded from the view of Hadfield (1996), Byrne (1996) and Angkana (2002), he definited play and game. Game is activities with fun and rules, the participants obey the rules and reach to the goal. Play lets participants get involved with the activities and enjoy with pleasure (Chen, 2000, pp. 97-105). Playing was created by children when they were not otherwise engaged in helping or learning (Brooking-Payne, 1996).

Moyles (2005, p. 4) clarifies general usage in English, play can be deemed to be the play or plaything in drama and toys; to play in relation to method or mode; to undertake something playfully; or distinguish any one meaning which in children's play; it makes more sense to consider the processing of play which, in itself, will subsume a range of behaviours, motivations, opportunities, practices, skills and understandings. Fergus P. Hughes (2000, p. 2) claims an activity can be described as play, it must contain five essential characteristics from Vandenberg. First, play is intrinsically motivated, it is an end in itself, done only for the sheer satisfaction of doing it. A second, related characteristic of play is that it must be freely chosen by someone who participates. A third essential characteristic of play is that it must be enjoyment. Children must be keep on the experience or it cannot be regarded as play. A fourth characteristic of play is that it is nonliteral. A fifth, a player must be active. Therefore, play must let the children get involved, physically, psychologically, or both, rather than passive or indifferent to what is going on. Game and play both has same meaning in Taiwanese and Mandarin. People have play and games all the time, yet people don't focus in this part which happens in our daily life all the time.

\section{Classical Theories of Play}

Play theories are divided into classical theories of play andmodern theories of play (Stagnitti, 2004; Mellou, 1994). Classical theoriesof play originated in the nineteenth century and tried toexplain the existence and purpose of play (Mellou, 1994). According to Johnson and Christie (1987), the classical theories of play all originated before World War I. They try to explain why play exists and what purpose it serves. The classical theories include surplus energy, recreation, recapitulation and practice theories, yet they can be grouped into two pairs. Hughes (1995) states early play theories, those that appeared in the latter part of the nineteenth century and the early years of the 12th, emphasized the biogenetic significance of play. That described that play is as an instinctive mechanism that either promoted optimal physical development or even reflected the evolutionary history of the human. 


\section{Surplus Energy Theory}

The surplus energy theory of play can be traced back of Triedrich Schillier, an 18th century German poet, and to Herbert Spencer, work accumulating a certain amount of engery to meet survival needs. That means any energy left over after these basic needs have been met become surplus energy. The extra energy builds up physical and mental presure and must be expended and relaxed. This explains that the surplus energy theory is still so popular today. Anyone who has seen young children run out to the playground after a long period of sedentary work in a classroom (Johnson \& Christie, 1987). The reasons for play in surplus energy is to discharge the natural energy of the body and get the greatest physical benefits in order to stay in healthy condition (Hughes, 1995).

\section{Recreation Theory}

The recreation theory proposed by the German poet Moritz Lazarus stated that the purpose of play is to restore energy expended in work. According to Lazarus, work burns up energy and creates an energy deficit of human body. The energy can be regenerated either by sleeping or by engaging in an activity which is not the same as the work that caused the energy deficit. The other way of work play doesn't work and that is the ideal way to restore lost energy (Johnson \& Christie, 1987). The reasons for play in renewal of energy or the effect of recreation theory is to avoid boredom and tiring while the natural motor functions of the body are restored, and it also gets the greatest physical benefits (Hughes, 1995).

\section{Recapitulation Theory}

Recapitulation theory was discovered by some scientistslast century, the human embryo develops and it appears to go through some of the same stages that occured in the human evolution. G. Stanley Hall, an American psychologist, extended this theory to children's play. According to Hall, children reenact the developmental stage of the human race in their play: animal, savage, tribal member, and so on. These stages of play follow the same order that they occurred in the evolution of human species (Johnson \& Christie, 1987). Recapitulation is not only to relive periods in the evolutionary history of the human species but also it gets physical benefits (Hughes, 1995).

\section{Practice Theory}

Practice theory was proclaimed by Philosopher Karl Groos who believed that play serves to strengthen instincts for the future needing. Newly born humans and animals inherit a number of imperfect, partially formed instincts that are essential for survival. Play offers a safe means for the young species to practice and perfect these essential skills. The purpose of play is to exercise and claborate skills necessitated for the children to fit their future life (Johnson \& Christie, 1987). Thus, play is to practice and prepare for the future adult life. Practice theory means to practice for adulthood and also to develop survival skills, necessary knowledge for being an adult which gets in physical and intellectual benefits (Hughes, 1995).

All the theories are either unrealistic or unreasonable because of limitation in those theories. Exceptions are found in each theory, for example, it is hard to explain why the children still want to paly even they are exhausted in the surplus energy theory of play. The recreation theory declares the purpose of play is to restore energy expended in work for adults but adults do not need more play than children. Although the classical theories are not perfect, they are still important in the play history and they are also the foundation stone to influence in modern theories of play. 


\section{Modern Theories of Play}

Modern theories were developed later 1920, and these theories endeavored to explain the role of play in child development (Stagnitti, 2004; Mellou, 1994). Modern theories of play amid an age dominated by the scientific method and positivism. Modern theories of play endeavor to do more than simply explain why it exists. They also try to determine the role of children's development and, in some cases, to specify antecedent conditions that cause play behavior. They also try to explain different aspects of play's role of child development (Johnson \& Christie, 1987; Ellis, 1973; Johnson, Christie, \& Wardle, 2005).

\section{Psychoannalytic Theory}

Sigmund Freud, the founder of psychoanalytic theory, believed that play plays an important role in children's emotional development. According to Freud (1996), play gets a cathartic effect that allows children to run away from negative feelings associated with traumatic events. Play also allows the children to suspend reality and switch roles from being the passive recipient of a bad experience to being the one who gives out the experience (Johnson, 1987). According to Johnson et al. (2005), play can help children to go through the unpleasant experience and can help prevent them from disrupting the child's emotional development. Play can have a cathartic effect, allowing children to rid themselves of negative feelings assocviated with traumatic events.

\section{Cognitive Theories}

Piaget $^{5}$, Vygotsky ${ }^{6}$ and others gained prominence in the United States in the late 1960s, Piaget who was the major in play theory and research. Between 1929 and the early 1959s, Piaget created a radically new theory of children's intellectual development. According to Piaget's theory, children engage in types of play that harmonize to their current level of cognitive development. When the children aquire the ability to use symbols, they start to engage in symbolic and constructive forms of play. Play's role in learning and development in Piagetian theory is somewhat complex. On the other hand, the theory supports that play, by its very nature, cannot contribute to new learning. Therefore, Piaget (1963) stipulated that play must adaptation of learning and development. That requires a balance between two complementary processes which are assimilation ${ }^{7}$ and accommodation $^{8}$. Piaget also believed that children practice and consolidate recently in order to acquire concepts and skills through accommodation by using play. Because assimilation is stronger than accommodation, this practice is critical. Piaget considered this practice and consolidation role of play really important, if the newlyacquired skills and comceptswere not repeated and integrated with other skills and concepts during play, they would be quickly lost. Vygotsky believed that play takes a direct role in cognitive development and young children are to be capable of abstract thought because of meaning and objects are used together as one.

\section{Arousal Modulation}

Arousal Modulation is theory claimed by D. E. Berlyne, G. Fein, and H. Ellis, which is to keep the body at

\footnotetext{
${ }^{5}$ Jean Piaget who was a Swiss psychologist crafted a radically new theory of children's intellectual development. His theory took hold in the United States during the 1960s, proposed that children go through a series of distinct stages during which their thought processes become increasingly similar to those of adults.

${ }^{6}$ Lev Vygotsky who was a Russian psychologist and he believed that play has several roles in cognitive development. At the most basic level, Vygotsky (1976) believed that make-believe play has a key role in abstract thought, enabling children to think about meanings independently of the objects they represent. According to Vygotsky, very young children are in capable of abstract thought because for them meaning and objects are fused to gether as one.

${ }^{7}$ Assimilation is the child to incorporate new information into exiting cognitive structure.

${ }^{8}$ Accommodation is the child to modify existing cognitive structures to conform to the reality of the physical world.
} 
an ideal condition of arousal, to reduce boredom and to relieve uncertainty. Arousal modulation gets benefits both of emotion and body, and one of the outstanding features of play is that it is basically motivated. It is done for no apparent reason other than the sheer satisfaction of doing it. The motivation for some behaviors, however, cannot be explained in terms of bsic physiological needs; these behaviors include play and exploration of the environment. Human beings, and lower animals as well, play with and explore their surroundings simply because they want to; there is no reason for these behavors attempted to explain play, therefore, by referring to the concept of internal, rather than external, motivation, and more specifically to the concept of arousal modulation (Hughes, 1995).

\section{Bateson's Theory}

Play, according to Bateson (Johnson, Christie, \& Yawkey, 1987), is paradoxical. Actions performed during play do not mean what they normally mean in real life. When children engage in play fighting, the blows delivered denote something very different from actual hitting. Before engaging in such play, children must establish a play "frame" or context to let others know that what is about to happen is play, that it is not real. If a play frame is not established, the other children will interpret the mock blows as a real attack and respond accordingly. When children play, they learn to operate simultaneously at two levels. At one level, they are engrossed in their pretend roles and focus on the make-believe meanings of objects and actions. Bateson's theory has stimulated interest in communicational aspects of play, prompting psychologists to examine the messages that children use to establish, maintain, terminate, and reinstate play episodes. It has led to the discovery that children constantly shift back and forth between their pretend roles and their true identities while engaging in sociodramatic play.

The modern theories support and help us to understand more about play and they attract the children in learning positively by using play in teaching. The current trend is towards play in teaching language (Chan \& Y. C. Lin, \& L. C. Lin, 2000, pp. 123-147). Play follows the spirit of instruction theory. In the processing of play, children are able to think in order to win the play without any certain modal. Play is flexible to settle the problems they have met during the play. Mother tongue is a new subject in Taiwan and play in teaching Taiwanese Romanization Spelling will provide an active, happy and interesting environment for the children to learn it. It becomes naturally in listening, speaking, reading, and writing. Shalva (2002) declares the purpose of play in teaching, play is not only play which leads all the students get involved in class activity and learning. Taiwanese Romanization Spelling needs more practice and skill to learn, play not only can help the children learn it without stress but also stimulate the motivation of learning.

\section{Why Play Is Important?}

Fox (2008), indicates that both Fromberg and Gullo (1992) described play enhances language development, social competence, creativity, imagination, and thinking skills. Frost (1992) concurred, stating that "Play is the chief vehicle for the development of imagination and intelligence, language, social skills, and perceptual-motor abilities in infants and young children" (Fox, 2008, p. 48).

Jill also mentions that when children play, they draw upon their past experiences-things they have done, seen others do, read about, or seen on television - and they use these experiences to build games, play scenarios, and engage in activities. Children use fine and gross motor skills in their play. They react to each other socially. They think about what they are doing or going to do. They use language to talk to each other or to themselves and they very often respond emotionally to the play activity. The integration of these different types of behaviors is key to the cognitive development of young children. Therefore, play is a very effective vehicle for learning. 


\section{Play and Cognitive Development}

Jill Englebright Fox (2008) also indicates that the relationship between play and cognitive development is described differently in the two theories of cognitive development which dominate early childhood education-Piaget's and Vygotsky's.

Piaget (1962) defined play as assimilation, or the child's efforts to make environmental stimulus match his or her own concepts. Piagetian theory holds that play, in and of itself, does not necessarily result in the formation of new cognitive structures. Piaget claimed that play was just for pleasure, and while it allowed children to practice things they had previously learned, it did not necessarily result in the learning of new things. In this view, play is seen as a "process reflective of emerging symbolic development, but contributing little to it" (Johnsen \& Christie, 1986).

In contrast, Vygotskian theory states that play actually facilitates cognitive development. Children not only practice what they already know-they also learn new things.

\section{Parten's Five Types of Play}

Play for young children believes in many different forms. Mildred Parten (1932) studied children at play, and she was one of the early researchers dealing with it. She focused on the social interactions between children during play activities. Parten's categories of play are not hierarchical. Depending on the situtations, children may engage in any of the different types of play. Parten does note, however, that in her research with two- to five-year-olds, "Participation in the most social types of groups occurs most frequently among the older children" (Parten,1932, p. 259).

The five types of play are as following:

(1) Onlooker behavior - To play passively by watching or conversing with other children engaged in play activities;

(2) Solitary independent-To play by oneself;

(3) Parallel - To play, even in the middle of a group, while remaining engrossed in one's own activity. Children playing parallel to each other sometimes use each other's toys, but always maintain their independence;

(4) Associative-When children talk to each other and share materials, but do not coordinate play objectives or interests;

(5) Cooperative - When children organize themselves into roles with specific goals in mind (e.g., to assign the roles of doctor, nurse, and patient and play hospital).

Play is as important as water to fish, sunshine, to plants, therefore play also plays chief role in learning to children. It attracts and guides them to focus in learning new things which lead them to dare with new knowledge, thus they learn how to beindependent and cooperative in class.

\section{Play, Games, Creativity, Problem-Solving, and Effect of Play}

Play and itsbehaviours which takes anextremely important role, as Moyles (2005, pp. 30-52) claims that grappling with the concept of play can be analogized to trying to seize bubbles or clouds, for every time there appears to be something to hold on to, its ephemeral nature does not allow us to grasp it. Play and learning for young children are inextricably linked, the one often leading into the other and the one often affecting the other one. The evidence of research has demonstrated that children's level of involvements and engagement in play activities is really an important indicator of their current level of development and learning and potential needs. 
Involvement and engagement being understood as active participation and motivation (Moyles, 2005; Odometal, 2004).

\section{Play and Language Teaching}

Janet R. maintains that Levy (1984) strongly sustained the relationship between play and language, on her conclusion she claimed that play is effective in learning languages and it also stimulates the expansion and creation of language learning. Play provides more language practicing and using and encourages language literacy. How play improves children's language literacy, in her evidence of play, children's language ability is expanded by play. Language includes phonology, is also concerned with pronunciation, syntactic consists of words and patterns componets, semantic-language notes to use it properly and pragmatics is effective interaction. Play to children is automatic and free product, it is provided with great imagination, creation, curiousness and mentality. The distinguishing characteristics of play in teaching are interesting, competition, cooperation, education and proper challenge, in which need to match with intrinsic quality of education, otherwise play is play without goal.

\section{Playing Games in Teaching Taiwanese Romanization Spelling}

Moyles (2005, p. 7) claims children have less and less time for play outside school, therefore, play is import to attract children to pay attention in class:

(1) Play is an essential part of children but it's hard to justify to the head and other teachers;

(2) Children really are tired to face the pressure-They do need to play more;

(3) They get their own first-hand experience while they are playing;

(4) Children's social skills would be improved by playing if we could provide more play;

(5) It's important to give them some choice when they've finished their work;

(6) Children trend easily to be tired of sitting down and need something active;

(7) They love doing messy things which theycan achieve a balance;

(8) I do believe that children learn through play but the work provides the written record.

For young children, play and learning are inextricably linked, the one often leading into the other. Using play or games in teaching combines with activities, motivation and interesting which leads children up the garden path (Zhang, 2007, pp. 13-14). Play in leaning focuses on the purpose in children's learning, the central idea to design play, games, or activities is children according to the four parts of language learning ( $\mathrm{Su}, 2002)$.

(1) Listening: The output to input, sound from the teachers transmits from ears to children's brain which is the nature teaching procedure;

(2) Speaking: No matter children like or dislike, they have to speak to get involved with play;

(3) Reading: Children participate with activities which use the reading ability to compete with the other competitors;

(4) Writing: Writing is an easy task while children areplayinggames the writing ability is incidentally brought up.

It also indicates (Yin, 2003) that using play or games in teaching will keep the interest of children to learn Taiwanese Romanization Spelling. Therefore, she concludes five aspects of play in teaching. A first, children feel tired after a long time learning Taiwanese Romanization Spelling, thus they do not pay attention in class or they feel low during class. If teachers support the children a game or an activity in the certain time, they will feel happy for five second, play highlights teaching: When teachers explain again and again, the children may 
not understand Taiwanese Romanization Spelling. Thus we use play and review to improve the children's Taiwanese Romanization Spelling ability. Third, let the children get used to speak Taiwanese fearlessly while they are having activities in class. Fourth, team work is the major part of play or games. The children help each other no matter they have different ability when they play games. Under the stimulus of this inspiring motive, children bustle about with new energy and team spirit. Fifth, warm up is opening, reviewing, closing and powerful method to use. Even small and easy game brings the children in the learning situation.

Action research encourages the researchers to quest, discuss, and judge through repeating thinking and practicing teaching procedure in order to understand the teaching situation then solves the problem and improves it (Cai, 2000, p. 1). The way action research works is very systematical and scientific, and it is flexiable policy to adjust and amend the educational problem. Action research combines action and research together which tries to shorten the theories and practical experience (Cai, 2000, p. 6). The teachers are researchers and real workers, not only do they realize how to teach effective but also judge when they get involved with teaching. Schon (1983) indicates, the teachers in action research are counselors,social psychologists and environment engineers. Each child may have different problems in class, in which come from individual family or personal pressure, thus good teachers know all the factors in learning and help the children instantly. Richard claims teaching is full of challenge and complexity and the distinguishing characteristic are as following (Richard, Stephanie, \& Deborah, 2002).

(1) Teaching is action.

What is the main concept of teaching, we define that teaching is an action. Teaching produces or inspires learning activity, in fact it embraces a professional specialty in each subject and transmits by teachers. How to lead children from the paper of books to be the part of children's studying? Effective and professional teachers should set the goal of teaching and activities, organize the class then they interact with the children to understand and help them. If the classroom rules have been set, the children will well know with them and follow the steps of learning from the teachers. Again, effective and professional teachers should prepare well in their specialty in subjects to be ready for transmitting knowledge.

(2) Teaching is art and science.

A teacher who knows how to teach effectively may not be an effective teacher because he must know how to transmit the curriculum which children would like to learn at first. E. W. Eisener (1982) indicates that a professional teacher not only designs a scientific curriculum but also teaches in artistic procedure. Richard claims that a successful teacher is a person of determination during the teaching activity. A teacher faces to different situtation of teaching contents, teaching methods, classroom management and adjusting dissimilar students immediately in order to attract the children attention in learning.

(3) Statistics is analysis language.

In many researches, statistics analyses are usually used to present the result. Statisics analyses tell significance to explain the difference of the data and prove the correlation between collection data and variance by no means fortuitous. Gân defines statistics is to collect, display, analyze, coordinate and explain the samples which infers the population and makes ascientific decision in the uncertain situation.

(4) Teachers are the action researchers.

J. T. Breuer and Richard suggests to improve education that correlation between researches and professional teaching should get closer. Teachers make the model of teaching through the unique in their 
researches. Doing researches and building the theory and making clear decision are on the basis of knowledge, experience, effective teaching method and making a self-examination by the teachers after teaching (J. T. Breuer 1993; Richard, 2002). Searching effective teaching method is as important as a thoughtful research. A successful teacher must be the action research.

(5) Teacher student truth experienceaction reflection experience action context evaluation: A practical approach

According to reflect, judge and make decision, teachers are the actional researchers who not only do the researches but also interact with the children. Thus an effective teacher should be an active participant and observer to proceed and explain the information he has collected during his teaching in class. To understand what he has done the procedures and to know why he has done them by reflecting and evaluating himself.

(6) Actional research

Work through the action research, an effective teacher is a professional teacher who proposes all sorts of hypotheses to explain, adjust, evaluate and amend his research. If he has collected as much as information and data then it is possible to proceed his actional research.

Wittrock and Farley (1989) claim that education connect with psychology, the learning principles, evaluation of learning and practical teaching experience, in fact that if a professional teacher is an artist, he requires more theories in his researches. Why does a teacher need more theories? J. T. Breuer (1993) indicates that theories bring out the function to fit researches. Sir Isaac Newton found Universal Gravitation help us why the apple falls down on the ground. Because of Universal Gravitation, the astronants flew to the moon and transimitted the view of the moon on TV. We should realize the theory leads inventions and let us understand psychology in order to use in education (Breuer, 1993; Richard, 2002). Action research is a method in different styles that you use to achieve any data by the researchers who are interested in different topics. Play in Taiwanese Romanization Spelling teaching is the first research on the purpose to help children learn Taiwanese Romanization Spelling happily and effectively. According to the benefits of play in teaching, we have used it in action research in Taiwanese Romanization in Spelling. In order to attract the children in class, we designing games in the curriculums, drill and demonstrate the games before class, and discuss the problems after teaching. Among the 13 weeks teaching, we finally collect the data from control group and experimental group. The data is analyzed by using SPSS. The children take the pre-test and post-test before teaching and after 13 weeks teaching.

\section{Score of Achievement Evaluation Test}

Data processing and analysis ${ }^{9}$ :

Before processingthe test, we set the pretest and post-test of consonants, vowels, terminal sounds, tone, spelling and overall performance as the covariate and take single factor anaiysis of covariance. Before taking single factor anaiysis of covariance, we inspect the relationship between the variate and dependent variable and the relevance of the inspection with variable and dependent variable in each group is the same, namely regression test of the homogeneity of within-class regression coefficient as the same, the results as shown on Table 1 consonants, vowels, terminal sounds, tone, spelling, and overall performance $\left(F_{(1,49)}=0.17\right.$, and 0.91 , and 0.48 , and 0.14 , and 1.77 , and $0.08, p>0.05$ ).

\footnotetext{
${ }^{9}$ I would like to thank my professor Chen Feng-Ru who has guided me to finish this research and also helped with the data processing.
} 
Table 1

All Variables Within the Group of Regression Homogeneity Test Results

\begin{tabular}{lrlrll}
\hline Sources of variation & $S S^{\prime}$ & $d f$ & $M S^{\prime}$ & $F$ & $\eta^{2}$ \\
\hline Consonants & 4.19 & 1 & 4.19 & 0.17 & 0.003 \\
Vowels & 19.64 & 1 & 19.64 & 0.91 & 0.018 \\
Terminal sounds & 10.95 & 1 & 10.95 & 0.48 & 0.010 \\
Tone & 6.58 & 1 & 6.58 & 0.14 & 0.003 \\
Spell & 25.16 & 1 & 25.16 & 1.77 & 0.035 \\
The overall performance & 19.77 & 1 & 19.77 & 0.08 & 0.002 \\
\hline
\end{tabular}

Note. ${ }^{*} p<0.05$.

\section{Results and Discussion}

(A) Experimental Treatment Effect. To process the consonants, vowels, terminal sounds, tone, spelling and overall performance of two groups on experimental treatments, we sort the variables of scores in two experiment groups. Set pre-test results as covariate, post-test results as the dependent variable, taking ANCOVA test and the analysis results as shown in Table 2 and Table 3.

Table 3 shows, in addition to outside terminal sounds $\left(F_{(1,50)}=2.08, p>0.05\right)$, with the remaining consonants, vowels, tones, spelling and overall performance in the experimental treatment groups were significant $\left(F_{(1,50)}=\right.$ 4.46, and 4.95, and 5.86, and 84.77, and 21.85, $p<0.05$ ), shows pre-test score effects of exclusion, two experimental groups of students on the consonants, vowels, tones, phonics and overall performance test scores, significant differences still exist. Moreover, compared the performance between the groups to the adjusted average (see Table 4), accept Play in Teaching Taiwanese Romanization Spelling experimental group of consonants, vowels, tones, spelling and overall performance scores were significantly higher than the control group students $(13.78>10.84$, and $12.67>9.70$, and13.04 > 8.40, $15.78>6.04,62.09>41.80)$.

Table 2

The Average and Standard Deviation of All Variables Before and After Measure Table Pro-test Post-test

\begin{tabular}{|c|c|c|c|c|c|}
\hline & $N$ & $M$ & $S D$ & $M$ & $S D$ \\
\hline \multicolumn{6}{|l|}{ Consonants } \\
\hline Experimental group & 23 & 9.74 & 4.56 & 14.09 & 4.65 \\
\hline Control group & 30 & 8.67 & 4.71 & 10.60 & 6.04 \\
\hline \multicolumn{6}{|l|}{ Vowels } \\
\hline Experiemental group & 23 & 6.61 & 4.41 & 13.91 & 5.83 \\
\hline Control group & 30 & 4.33 & 4.70 & 8.73 & 6.84 \\
\hline \multicolumn{6}{|l|}{ Terminal sounds } \\
\hline Experimental group & 23 & 3.39 & 4.28 & 8.17 & 4.67 \\
\hline Control group & 30 & 2.33 & 2.52 & 5.80 & 5.13 \\
\hline \multicolumn{6}{|l|}{ Tone } \\
\hline Experimental group & 23 & 3.13 & 2.94 & 13.04 & 5.42 \\
\hline Control group & 30 & 3.13 & 2.25 & 8.40 & 7.92 \\
\hline \multicolumn{6}{|l|}{ Spell } \\
\hline Experimental group & 23 & 5.91 & 3.79 & 16.00 & 3.41 \\
\hline Control group & 30 & 4.93 & 6.19 & 5.87 & 4.90 \\
\hline \multicolumn{6}{|c|}{ The overall performance } \\
\hline Experimental group & 23 & 28.78 & 12.47 & 65.22 & 17.29 \\
\hline Control group & 30 & 23.4 & 18.46 & 39.4 & 24.34 \\
\hline
\end{tabular}


Table 3

All Variables Post-Test Score Total Variable Analysis Summary Table

\begin{tabular}{lrrrrl}
\hline Sources of variation & \multicolumn{1}{c}{$S S^{\prime}$} & $d f$ & $M S^{\prime}$ & \multicolumn{1}{l}{$\eta^{2}$} \\
\hline Consonants shared variables & 336.92 & 1 & 336.92 & $13.55^{*}$ & 0.213 \\
Experimental group & 110.80 & 1 & 110.80 & $4.46^{*}$ & 0.028 \\
Vowels shared variables & 1275.14 & 1 & 1275.14 & $59.49^{*}$ & 0.543 \\
Experimental group & 106.08 & 1 & 106.08 & $4.95^{*}$ & 0.090 \\
Terminal sounds shared variables & 127.43 & 1 & 127.43 & $5.59^{*}$ & 0.100 \\
Experimental group & 47.53 & 1 & 47.53 & 2.08 & 0.040 \\
Tone shared variables & 69.99 & 1 & 69.99 & 1.46 & 0.028 \\
Experimental group & 280.86 & 1 & 280.86 & $5.86^{*}$ & 0.105 \\
Spell shared variables & 341.66 & 1 & 341.66 & $23.66^{*}$ & 0.321 \\
Experimental group & 1224.45 & 1 & 1224.45 & $84.77^{*}$ & 0.629 \\
The overall performance shared variables & 15378.01 & 1 & 15378.01 & $64.77^{*}$ & 0.564 \\
Experimental group & 5187.01 & 1 & 5187.01 & $21.85^{*}$ & 0.304 \\
Errors & 14457.83 & 50 & 289.16 & & \\
\hline
\end{tabular}

Note. ${ }^{*} p<0.05$.

Table 4

All Variables Post-Test Adjusted Average, and Afterwards

\begin{tabular}{|l|l|l|l|}
\hline & $N$ & Adjusted average & After comparing \\
\hline consonants & 23 & 13.78 & Experimental group $>$ Control groups \\
Experimental group & 30 & 10.84 & \\
Control group & 23 & 12.65 & Experimental group $>$ Control groups \\
\hline Vowels & 30 & 9.70 & \\
Experimental group & 23 & 7.93 & Experimental group $>$ Control groups \\
Control group & 30 & 5.99 & \\
\hline Terminal sounds & & & \\
Experimental group & 23 & 13.04 & Experimental group $>$ Control groups \\
Control group & 30 & 8.40 & \\
\hline Tone & 23 & 15.78 & Experimental group $>$ Control groups \\
Experimental group & 30 & 6.04 & \\
Control group & 23 & 62.09 & \\
\hline Spell & 30 & 41.80 & \\
Experimental group & & & \\
Control group & & & \\
\hline The overall performance & & & \\
Experimental group & & & \\
Control group & &
\end{tabular}

Table 4 shows the scores of terminal sounds in experimental group and control groups were not significantly. The students who were interviewed after thepost test appeared that terminal sounds were easy to identify. It is interesting to find it out, but there isn't more evidence to support that. It's conserved to discuss later on.

\section{Conclusion}

Overall, the use of play in teaching Taiwanese Romanization Spelling improved the organization and clarity of learning Taiwanese in the four aspects and it was implemented. Students indicated that they had a better understanding of Taiwanese Romanization Spelling and were able to write about each word in a more concise and deliberate manner. After the research, we are surely to conclude that play help children to learn Taiwanese Romanization Spelling and even Taiwanese. We also suggest that the teachers who are teaching 
Taiwanese Romanization Spelling should use play in their teaching or expand it in other subject teaching. Building a data base of play is in a hurry for the education department.

\section{References}

Alan G. Launder. (2001). Play practice: The games approach to teaching and coaching sports. Champaign, I.L.: Human Kinetics. Andrew, W. (1984). Games for language learning. Cambridge Handbooks.

Angkana, D. (2002). Games in the ESL and EFL class. The Internet TESL Journal, 8(9). Longman Group, UK: Games Teaching Oral English Harlow.

Anthony, Ch., \& Kurt, S. (1984). Play and practice: Graded games for English language teaching. Taipei : Crane.

Barbara, Sh. (2008). One hundred and one interesting games to stimulate IQ. Taipei: Psychological Publishing Co., Ltd..

Bennett, N. (1937-1997). Teaching through play: Teachers' thinking and classroom practice. Buckingham; Philadelphia: Open University Press.

Britz-Crecelius, H. (1920-1996). Children at play: Using Waldorf principles to foster childhood development. Rochester, Vt. : Park Street Press.

Broadhead, P. (2004). Early years play and learning: Developing social skills and co-operation. London: Routledge Falmer.

Brooking-Payne, K. (1996). Games children play: How games and sport help children develop. Stroud, Gloucestershire, UK: Hawthorn Press.

Cai, Q. T. (2000). Action research of education. Tapei: Wunan.

Cai, Q. T. (2000). Creative curriuclums. Tapei: Wunan.

Cai, S. L. (2004). The application of game theory-Infant child and infant child teacher. Tapei: Wunan.

Calabro, E. (2003). Rational emotive behavior play therapy vs. client centered therapy. Ann Arbor, Mich.: UMI Dissertation Services.

Chan, Lin, Y. C., \& Lin, L. C. (2000). Competitive and cooperative games in EFL elementary school classroom. Handbook of Education in NTNU. Department of Education in National Taiwan University.

Charles, E., Schaefer, H., \& Gerard, K. (2008). Contemporary play therapy: Theory, research, and practiceledited by Charles E. Schaefer, Heidi Gerard Kaduson. New York, N.Y.: Guilford Press.

Chen. A. H. (1999). Creating an amazing classroom: Games. Journal of STU, 24.

Chen, S. N. (2010). Using Taiwanese in Chinese teaching-A case in Grade one of elementary school. (Unpublished Master thesis, NTNU, Department of Taiwan Culture, Language and Culture).

Chen, Z. Y. (2000). The Chinese translation of game. Sports of Administration Journal, 29(4), 97-105.

Cohen, D. (1993). The development of play. London: Routledge.

Colin, B. (1996). Language revival and reversal: Foundations of bilingual education and bilingualism. Professor Ofelia Garcia, School of Education City College of New York.

Cummins, J. (2001). Bilingual children's mother tongue: Why is it important for education? King-an Literature and Teaching Magazine, 5, 82-89.

David, E. (2007). Children of 2020: Creating a better tomorrow. Taipei: JioChio.

Deborah, S. B. (2002). The foundations of students' learning. Thomson, Singapore.

Deborah, J. S. (1998). Motivation to learn second edition from theory to practice. Massachusetts USA: Allyn and Bacon.

Dei, Y. Y. (1999). The new trend of English-English teaching method in the elementary school (pp. 2-23). Taipei: Crane.

Digital Archive Database for Written Taiwanese (2nd stage). Retrieved from http://xdcm.nmtl.gov.tw/dadwt/pbkasp

Edgar, K., \& Sara, S. (1999). Children's game and learn. Taipei: Crown.

Elizabeth, W., \& Jane, A. (1955-2005). Play, learning and the early childhood curriculum. London: Paul Chapman Publishing.

Englebright Fox, Ph.D. Back-to-Basics: Play in Early Childhood. Retrieved from http://www.earlychildhoodnews.com/earlychildhood/article_view.aspx?ArticleID=240

Fishman, J. (1988). Language and ethnicity in minority sociolinguistic. USA: Multilingual Matters.

Fishman, J. (1985). The significance of the ethnic-community mother-tongue school. In J. Fishman (Ed.), The rise and fall of ethnic revival: Perspectives on language and ethnicity (pp. 363-376). New York: Mouton.

Games in teaching english in elementary schools. Retrieved from http://www.jszyw.cn/Article/bzluw/yuluw/200601/8943.html

Grade One to Nine Curriculum and Teaching. Retrieved from http://teach.eje.edu.tw/9CC/fields/2003/language02-source.php

Grade One to Nine Curriculum Mother Tongue Learning. Retrieved from http://iug.csie.dahan.edu.tw/TG/TGLMJ/index.htm \& $\mathrm{http}: / /$ www.sinology.info/principle.doc 
Guan, P. W. (2003). Our Taiwanese. Taipie: Focus San Creating Co..

Gui, S. C., \& Ning, C. Y. (1997). Theory of language. Shanghai: Shanghai Foreign Language Education Press.

Harold, A. L., Christine, B. S., Lerch, H. A., \& Geoffrey, E. M. (1953). Developmental moter activities for all children: From theory to practice. Dubuque, I. A.: Brown \& Benchmark.

Herron, R. E. (1982). Child's play. Malabar: John Wiley \&Sons, Inc..

Hoorn, J. V. (1993). Play at the center of the curriculum. New York: Macmillan.

Huang, G. H. (1999). Theories of Taiwanese teaching. Taipei: Cei Publish.

Hughes, F. P. (2000). Children games. Taipei: Hungyeh Publishing Co., Ltd..

Hughes, F. P. (1999). Children, play, and development. Boston: Allyn and Bacon.

Jack, C. R., \& Theodore, S. R. (1997). Language teaching. Taipei: Wunan.

James, A. B., \& Cherry, A. M. (2008). Multicultural education: Issues and perspectives. Paperback-September 8, 2009.

Janet, R. M. (2000). Just playing. Taipei: Psychological Publishing Co., Ltd..

Janet, M. (2005). The excellence of play. Maidenhead: Open University Press.

Janet, R. M., Duan, H. Y., \& Huang, X. H. (2000). Not only games-The role and position of games. Taipei: Psychological Publishing Co., Ltd..

Jones, E. (1930). The play's the thing: Teachers' roles in children's play. New York, NY: Teachers College Press.

Johan, H. (1998). Human: Player. Guilang, Guizhou Renmin Chuban She.

John, A. (1996). Effective movtivation. Pans Books.

Johnson, J. E. (1987). Play and early childhood development. London: Scoot, Foresmen and Company.

Johnson, J. E., \& James, E. (1947-2005). Play, development, and early education. Boston, M.A.: Pearson/Allyn and Bacon.

Johnson, J. E., Christie, J. F., \& Yawkey, T. D. (2003). Children games-developement. Theory Journal of Education \& Psychology, 35(2).

Johnson, J. E., Christie, J. F., \& Wardle, F. (2008). Play development and early education. Taipei: Farteng.

Jiang, N. Y. (2007). Action research in using games to improve poor literacy. Handbook of Special Education (pp. 13-34), NTU Department of Special Education.

Jiang, C. P. (1998). Active Taiwanese teaching-Speaking Taiwanese well. The Journal of Teachers, 39(3), 10-16.

Kathleen, A. R., \& James, F. Ch. (2007). Play and literacy in early childhood: Research from multiple perspectives. New York, NY: Lawrence Erlbaum Associates.

Li, C. A. (2007). Taiwanese romanization spelling in pictures. Tainan: King-an.

Li, C. A. (2001-2004). Chieh-Ting Yeh, Marian Lee. Hardard Taiwanese 101.

Li, C. A.(2000). The basic of Taiwanese. Tainan: Jen Pin.

Li, L. J. (1998). Whole language. Taipei: Hsin-yi. Org.

Li, L. J. (2006). Whole language education. Taipei: Psychological Publishing Co., Ltd..

Li, T. L. (1990). The value of games in teaching. Teaching Journal, 30, 33-36.

Liao, F. Y. (2008). Action research of Taiwanese romanization teaching. (Unpublished Master thesis, NTTU).

Lin, Y. W. (2002). Taiwanese romanization curriculum arragement in the elementary school. Taiwanese Romanization Meeting at Taitung in 2000.

Lin, Y. W. (2003). Elementary school learn Taiwanese-Dialects roman alphabet confusing with English (Unpublished Master thesis, NHCUE).

Lin, J. X. (1990). The method of Taiwanese teaching. Tainan: TDI.

Lin, C. X. (2001). An introduction of Taiwanese. Taipei: Psychological Publishing Co., Ltd..

Lin, C. X. (1996). An examination of Taiwanese symbols system. Sun Yat-sen Journal of Humanities, 4, 23-25.

Lin, C. Z. (2002). Effective teaching-Theory and Strategy-tactics. Taipei: Wunan.

Liz, W., \& Jane, A. (1996). Play, learning and the early childhood curriculum. London: Paul Chapman.

Loscher, A. (1998). Everybody play!: Group games and activities for young people. Toronto: Sport Books Publisher.

Lu, G. C. (2006). An introduction of Taiwanese. Taipei. SMC Publish Inc..

Ma, C. Q. (2008). MinTaiMinNanFangyYunshu Bi Jiao Yan Jiu. Peijing, ZuongGuoSer Hui Ke Publish.

Marshall, D. F. (1994). Language maintenance and revival. Annual Review of Applied Linguistics (1993/1994), 14, 20-33.

Margaret, K., Sheridan, G. M. F., \& Sara H. R. (1995). Using the supportive play model: Individualized intervention in early childhood practice. New York: Teachers College Press.

Mary, D. S. (1999). Play in early childhood: From birth to six years. London: Routledge. 
McKeman, J. (1996). Curriculum action research: A handbook of methods and resources for the reflective practioner. London: Kogan Paul Byme D.

McHiff, J., Lomax, P., \& Whitehead, J. (1996). You and your action research project. London: Routledge.

Mellou, E. (1994). Play theories: A contemporary review. Early Child Development and Care, 102, 91-100.

Moriboys, A. (2005). Teaching with emotional intelligence: A step-by-step guide for higer and futher education professionals. London; New York: Routledge.

Mother Tongue Family. Retrieved from http://iug.csie.dahan.edu.tw/TG/MTFamily/MTFamily.htm

Moyles, J. R. (1994). The excellence of play. Buckingham: Open University Press.

Nancy, K. F. (1994). Children's play and teacher-child interactions in integrated early childhood programs. Michigan: A Bell \& Howell.

National Digital Library Theses Disserations in Taiwan. Retrieved from http:etds.ncl.edu.tw/theabx/index.html Parten, M. (1932).

Social participation among preschool children. Journal of Abnormal and Social Psychology, 27, 243-269.

Noffke, S. E., \& Stevenson, R. B. (1995). Educational action research: Becoming practically critically. New York: Columbia University Teacher College.

Peng, D. M. (2000). Learning pronunciation and teaching strategies. Cave English Teaching Magnize, 26, 9-11.

Pintrich, P. R., Richard, D. P., \& Stephanie, L. H. (1996). Motivation in education: Theory, research, and applications. Englewood Cliffs, N.J.: Merrill.

Pugmire-Stoy, M. C. (1992). Spontaneous play in early childhood. New York: Delmar Publishers Inc..

Richard, D. P., Stephanie, L. H., DebroahStardo, B. et al. (2005). Educational psychology. Taipei: Hung Yehcom.

Robert, K., \& Hendrik, H. (2006). Play loud!. Berlin : Die Gestalten Verlag.

Scarlett, W. G. (2005). Children's play. Thousand Oaks: Sage Publications.

Schaefer, C. E. (1986). Game play. New York: John Wiley and Sons.

Schon, D. A. (1987). Educating the reflective practitioner. London: Jossey-Bass.

Seach, D. (2007). Interactive play for children with autism. Abingdon,Oxon: Routledge.

Shen, Z. R. (2006). Using games in English alphabet (Unpublished Master thesis, NTUE, Department of Child Psychology).

Smith, P. K.(2010). Children and play. Alden, MA : Wiley-Blackwell.

Shu, Q. (2002). 100 kind of English games. Taipei: U-Best.

Stagnitti, K. (2004). Understanding play: The implications for play assessment. Australian Occupational Therapy Journal, 51, 3-12.

Stipek, D. J., \& Schon, D. A. (1983). The reflective practioner: How professionals think in action. New York: Baxic Books.

Taiwanese Romanization Spellingin Learning. Retrieved from http://ws2.chkops.kh.edu.tw/newholo/learn_3/main.htm

The Education Department of Taiwan. (2007). Brochure of Taiwanese romanization spelling. Taipei.

The Education Department of Taiwan. Retrieved from http://www.hyes.tyc.edu.tw/nine/

Tong, J. C. (1997). Practical mother tongue education and theory. The World of Chinese, 86, 51-61.

Tu, C. J. (2001). Learning fun-Games in Hakka teaching. Institute of Taiwan Languages and Language Teaching Journal, 3.

Wei, X. (2004). Mother tongue spelling improved. Tainan: Fu Wen Books Co., Ltd..

Wilson, R. A. (1943). Nature and young children: Encouraging creative play and learning in natural environments. London: Routledge Co., Ltd..

Wong, Q. (2007). Action research of english teaching. Shanghai: Shanghai Foreign Language Education Press.

Wood, E. (1955-2005). Play, learning and the early childhood curriculum. London: Paul Chapman Publishing.

Wu, M. L. (2002). Action research in education. Taipei: Wunan.

Wu, S. L. (2003). Child and game development. Taipei: Yang-Chih Book.

Wu, Z. T. (2007). Education policy anlaysis. Taipei: Edubook.com.tw.

Xie, G. P. (1985). An introduction of language. Taipei: Sanmin com.

Xie, J. S., \& Yin, C. F. (2000). Using games in the EFL classroom. Taipei: CET.

Xie, G. P. (1995). Bilingual eduction and language scheme. The World of Chinese, 75, 32-33.

Xie, W. Y., \& Hong, J. F. (2007). Using games in science strategy-tactics model and teaching self-examination. NPUE Education Journal, 33, 232-258.

$\mathrm{Xu}, \mathrm{C} . \mathrm{H}$. (2005). Action research in whole language in grade 5 to 6 (Unpublished Master thesis, NHCUE, Institute of Taiwan Languages and Language Teaching).

Xu, C. M. (2002). Taiwanese course. Taipei: Frontier. 
Xu, Y. R. (2001). Games in teaching speaking curriculum. Teachers' Talk, 150, 38-42.

Yin, C. F., Xi, Q. S., \& Sun, S. C. (2003). Phonics in teaching. Taipei: CET.

Young, W. Y. (2003). The competition of Taiwanese symbols examples in TLPA and Romanization. Hand book of Taiwanese 2003 (pp. 45-60). Kaoshiong, Jian Ko Elementary Shcool.

Yoo, J. W. (1996). Games in teaching math in the elementary. Taipei.

Young, J. H. (1999). Welcome the multi-languages—Discussing about English education. Taiwan Education, 6, 14-16.

Young, S. Z. (1995). Discuss and analysis of games in the classroom. NCYU Jurnal, 9, 697-709.

Zhang, D. R. T. (2007). Instructional action research: Practical handbook and theory. Tapei: EDU Book.

Zhang, R. F. (2003). Basic of Taiwanese pronunciation. Taipei: Crane.

Zhang, Y. H. (2001). A theme for discussion Taiwanese. Taipei: Crane.

Zhang, Y. J. (2003). The meaning and facts of games (Unpublished Master thesis, Philosophy at Tunghai).

Zheng, L. Y. (1931). The changing language in Taiwan social: Multi-language and bilingual education. Taipei: ID News Publish. Zhong, R. F. (2006). An introduction of language. Tapei: Wunan.

Zhou, C. Q., \& Kang, C. M. (1997-1999). Taiwanese teaching curriuclum. Ping Tung: An Ko. 